\title{
COMMUNICATING BRAND PERSONALITY: THE MODERATING ROLE OF HUMAN PERSONALITY
}

\author{
Makam S. Balaji and Srividya Raghavan \\ IBS Hyderabad
}

\begin{abstract}
This research investigates the influence of individual personality on perception of brand personality when information is processed from advertisement. An experiment was designed to investigate the role of individual personality and personal relevance in moderating the relationship between advertising and brand personality perceptions. Results reveal that advertising or communication program plays a key role in perception of brand personality. Further analysis with MANCOVA indicates that, individual's personality dimensions do influence certain brand personality dimensions. This implies that communicating a designated brand personality is influenced by the personality traits of the target audience.
\end{abstract}

Keywords: brand personality; personality; personal relevance; marketing communication; advertising

Consumers often personalize brands by humanizing them. Humanizing or attributing human characteristics empowers the brand in helping it play a more central role in consumer's life. Because brands acquire symbolic meaning, it enables consumers to project different aspects of their actual self (Grubb and Hupp, 1968; Aaker, 1999). Brand personality facilitates consumers to choose a brand that is perceived to be consistent with their own self-concept and establish desirable consumer-brand relationships (Fournier, 1998). Research in brand personality suggests numerous implications of self-congruence. A fit between self-concept and brand personality leads to more favorable product evaluation or product attachment (Hegleson and Supphellen, 2004; Freling and Forbes, 2005). Self-congruence may affect brand performance (Mangleburg et al. 1998) by influencing the consumer attitudes and their buying decisions (Hamm and Cundiff, 1969). Brand personality contributes to brand equity by differentiating the brand from its competitors (Aaker, 1996), enhancing brand trust and preference (Sirgy, 1982; Fournier, 1998), and improving loyalty (Kressman et al., 2006). Kim and his colleagues (2005) indicate that self-congruence promotes emotions of love, pride, and joy thereby helping to build long-term brand relationship through the process of building self-esteem.

Brand personality is the set of human personality traits that forms the core component of brand identity. While marketing communication, especially advertising, is used heavily to create brand personality, it is derived as a parallel to human personality (Martineau, 1958; Aaker, 1997; Plummer, 2000). Human personality and brand personality are distinct, stable and have independent effect on brand choice (Helgeson and Supphellen, 2004; Wee, 2004). However, consumers often transfer their self expression to brands they purchase and influence how a brand personality is perceived. Phau and Lau (2001), for example, show that consumer's self plays a significant role in perception of brand personality. Furthermore, as consumers become loyal they project their personalities on to the brand to express their self-concept. This suggests that consumers may see a brand in different ways and bring in diverse personalities. The above argument is structurally similar to the one offered by Sung and Tinkham (2005, p. 336) who posited that brand personality is a "hypothetical construct developed by consumers". Thus, the perception of brand personality is subjective and could differ from the designated personality communicated by the marketing communication program.

While various studies have noted the possibility of envisaging a personality for a brand and the influence of brand personality on consumer's responses towards the brand (Caprara, Barbaranelli, and Guido, 2001; Freling and Forbes 2005), few studies have sought to understand how human personality variations may affect the perception of brand personality (Matzler, Sonja, and Sonja, 2006). Further, the marketing communication program (Batra, Lehmann and Singh, 1993) and personal relevance (Petty, Cacioppo and Schumann, 1983) play a key role in processing brand information and shaping the designated personification of a 
brand. This study aims to explore the moderating effect of individual's personality in influencing the relationship between marketing communications and brand personality perceptions. In addition, the study also examines the role of personal relevance in creating brand personality. The paper is organized as follows. In the first section, the conceptual framework of the study is presented through a literature review on human personality and brand personality. Method and analysis are then presented. Finally, the discussion of the results obtained and the limitations are presented in the last section.

\section{Human Personality}

\section{CONCEPTUAL FRAMEWORK}

A major area of research in psychology since early 20th century has been exploration and validation of constructs that represent the fundamental personality traits (John and Srivastava, 1999). According to Ajzen (2005, p. 2) personality traits are "characteristics of an individual that exert pervasive influence on a broad range of trait-relevant responses". Among a plethora of personality trait theories proposed (Allport and Odbert, 1936; Cattell, 1943; Fiske, 1949; Smith, 1967; Goldberg, 1981), a popular and more general demarcation of individual personality is made possible by the "Big Five" model (McCrae and Costa, 1990).

The Big Five model using a trait analysis approach describes the individual personality differences based on five human traits namely extraversion, agreeableness, conscientiousness, neuroticism (emotional stability) and openness to experience. Extraversion refers to an extent to which an individual is outgoing, friendly and talkative and is associated with behaviors such as sociability, liveliness, and self-confidence (McCrae and Costa, 1990). Agreeableness refers to a tendency towards being trusting and cooperative. Being courteous, forgiving, modest and flexible are some of the behaviors associated with individuals with high agreeableness (Cooper, 2003). Hostility and selfishness are the associated behaviors in individuals with low agreeableness (Bozionelos and Bennett, 1999). Conscientiousness includes the ability to be organized, responsible, thoughtful, and achievement oriented (Costa, McCrae and Dye, 1991). Neuroticism is associated with behaviors such as anxiousness, insecurity, depression, and worry (Barrick and Mount, 1991). The opposite of neuroticism is known as emotional stability. Emotionally stable people tend to be imperturbable, self-assuring and confident (Hills and Argyle, 2001). The last trait openness to experience refers to the tendency towards being imaginative, intelligent, curious and cultured (McCrae, 1994). Thus, the five traits in combination capture a significant part of the individual's personality.

According to John and Srivastava (1999, p. 103), "the Big Five taxonomy serves an integrative function because it can represent the various and diverse systems of personality description in a common framework". In marketing, the personality traits were of high interest because they were thought to predispose individuals to particular behaviors. Various consumer related activities such as purchase intentions, choice and disposition, coping strategies, product attachment, interactions, word-of-mouth communication, and information processing (Duhachek and Iacobucci, 2005; Mooradian and Swan, 2006; Mowen, Park, and Zablah, 2007; Kaltcheva, and Parasuraman, 2008) have been related to personality. In addition, personality is often used as metaphor to define brand preference and position. Fournier (1998) used this metaphor of brand as the personified individual to describe the consumer-brand relationship. Self-congruence, the fit between consumer's personality and brand personality, impacts brand performance and increases brand loyalty (Kressmann et al., 2006).

\section{Brand Personality}

Aaker (1997, p. 347), in her landmark study of consumer brands described brand personality as "the set of human characteristics or traits that consumers attribute to a brand". Brand personality reflects how consumers feel being associated with a brand and forms an important objective of brand management (Keller, 1998). Based on the Big Five or five-factor 
model (McCrae and Costa, 1990), Aaker (1997) proposed a brand personality measure consisting of 42 individual personality traits and five dimensions: sincerity, excitement, competence, sophistication, and ruggedness. Follow-up analyses (Aaker, 1999, Aaker, BenetMartinez and Garolera, 2001) indicate that these dimensions are stable, valid and reliable measures of the brand personality within a particular category. Brand personality is an important factor for the success of the brand and a strong and favorable brand personality will have a greater number of strong and unique brand associations resulting in increased preference, usage and loyalty (Freling and Forbes, 2005).

Acustomer's perceived brand personality can be formed in several ways. User imagery defined as the set of human characteristics associated with stereotype user of the brand could be the primary drivers of a brand personality (McCracken, 1989). Other direct ways include the transfer of characteristics from the company's employees, spokesperson, endorsers and CEO (marketing communication mix). Indirectly the brand personality can be created by productrelated characteristics (product class, packaging, price, and product attributes) and nonproduct related characteristics (symbol, sponsorship, country of origin, and age) (Batra et al., 1993).

Marketing actions, especially advertising is heavily used to communicate the product's meaning and create brand personality (Batra et al., 1993; Meenaghan, 1995; Blythe, 2007). Advertising is considered as an effective tool in influencing the brand evaluation through evocation of brand associations. Advertisements create symbols and imagery around the advertised product and communicate the designated brand personality. Further, the way consumers process advertisement stimuli influences brand personality perceptions. Ruiz and Sicilia (2004) show that individual personalities drive information processing and consecutively influence their perception of the brand. Consumers are more susceptible and receptive to advertising messages that match their personalities (Moon, 2002). Matzler and his colleagues (2006) propose that human personality differences can account for differences in the values and expectations of the consumer. An individual's propensity to extraversion has been associated with energy, ambition and venturesome and this dimension has been shown to influence brand loyalty and behavior. Other personality dimensions, such as neuroticism and openness to experience have the propensity to influence perception, preference and choice of brand (Dollinger, 1995; George and Zhou, 2001). Fennis, Pruyn and Maasland (2005) in their study suggest that brand personality dimensions affect individual assessment of personality traits. In a series of four experiments, the authors found a transfer effect from brand personality traits to consumer personality traits. Furthermore, the results suggest that the brand personality dimensions of extraversion, sincerity and competence affected the Big-Five factors of ruggedness, agreeableness and intellect respectively.

\section{Communication and Information Processing: Role of Personal Relevance}

MacInnis and Jaworski (1989), present a conceptual model of information processing from advertisements wherein, motivation, opportunity and ability (MOA) were shown to influence the capacity and attention for processing brand information from advertisements. Motivation to process information has been conceptualized in literature as involvement (Petty and Cacioppo, 1986; Richins and Bloch, 1986). Involvement is defined as "a motivational state that affects the extent and focus of consumers' attention and comprehension processes" (Celsi and Olson, 1988, p. 210). Petty, Cacioppo, and Goldman (1981) present the role of involvement in moderating the information processing elicited by advertisements. High involvement (HI) leads message recipients to systematically process information, while low involvement (LI) led to heuristic processing (Chaiken, 1980; Eagly and Chaiken, 1984). Furthermore, processing advertising messages can be automatic or strategic and the level of one's involvement with the product plays a moderating role in the process (Berger and Mitchell, 1989; Fennis and Pruyn, 2007). 
In sum, we can hypothesize that individual's personality influences the processing of advertising message and brand information and affects perceptions of brand personality. More specifically, we empirically test the moderating effect of individual's personality in perceptions of brand personality. This has fundamental implications for brand personality and image literature, communication strategy literature, and practicing managers. Further, personal relevance influences the relationship between marketing communication and perception of brand personality.

\section{METHODOLOGY}

The primary purpose of this study was to investigate the moderating influence of individual's personality in perception of brand personality. This is based on the premise that individual's personality affects message processing and may influence the perception of brand personality being communicated. The present study is set in the context of individuals processing information from advertising communication. Hence, the study involves examination of the role of exposure to advertising as well as the role of personal relevance in creating brand personality. Figure 1 presents the diagrammatic representation of the relationship construed among the variables. An experiment was designed to investigate the above proposition that individual's personality moderates the influence of marketing communication in creating brand personality. Our study was conducted in the context of corporate brands in Information Technology (IT) industry.

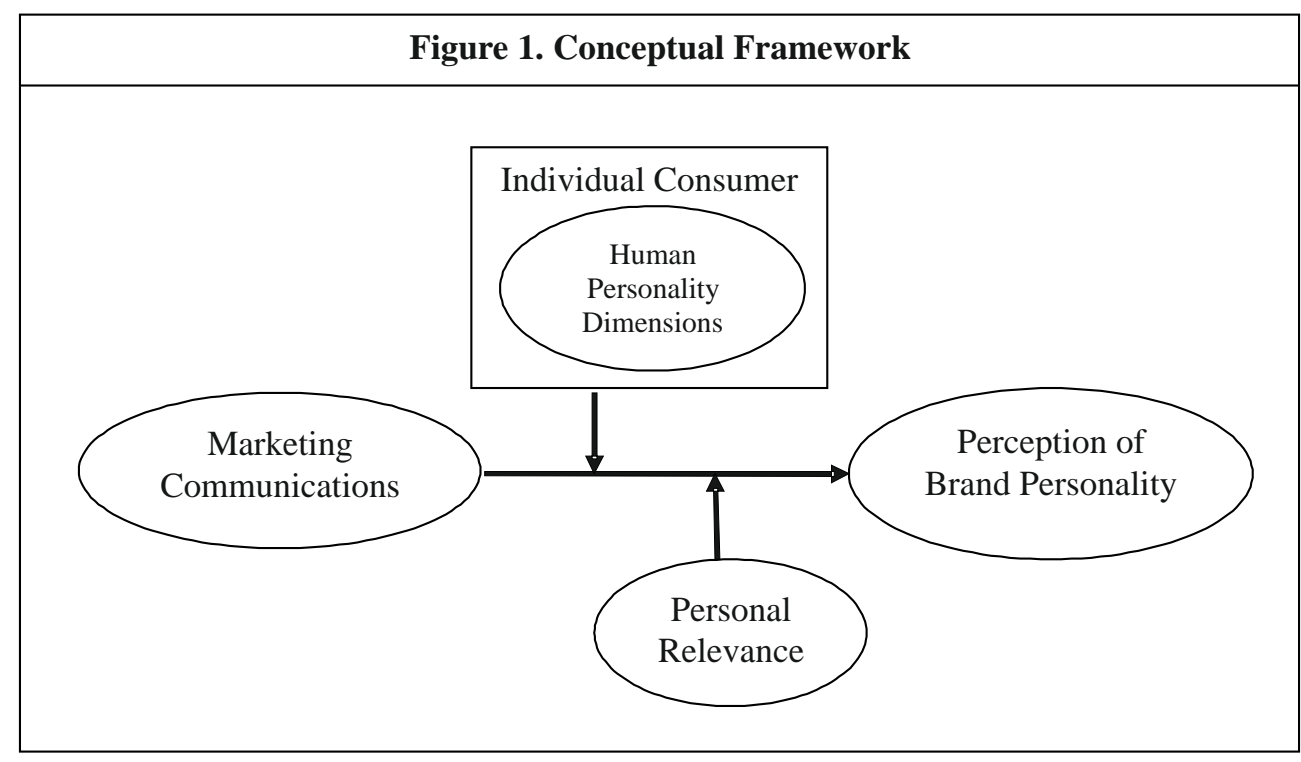

\section{Participants and Procedure}

The study was done in three stages. In the first stage, a standardized instrument to measure the Big Five personality dimensions (Big Five Inventory - BFI: John and Srivastava, 1999) was administered to one hundred and thirty five students who were enrolled into the post-graduate degree program at a large business school in South Asia. Scales were computed for each of the personality dimensions-extraversion, agreeableness, conscientiousness, openness and neuroticism-for analyzing the moderating role of individual personality dimensions on perception of dimensions of brand personality. In addition to the 44 statements that comprise the personality questionnaire, the participants indicated their immediate placement and future career prospect (ranking) among various industries such as manufacturing, information technology, hospitality and others. This was used to classify the participants into high and low relevance groups. 
In the second stage, the participants were contacted for awareness regarding various IT companies (corporate brands) and their communication programs. Based on the responses provided, HCL (Hindustan Computers Limited) and Apple were selected for further analysis. HCL is a global leading technology and IT enterprise company and offers various products spanning R\&D and technology services, telecom products, BPO services and many more. Apple, a multinational company, designs and manufactures consumer electronics and software products such as Mac, iWork, iPod and others. The two companies have high awareness and low advertisement recall among the participants.

After two weeks of initial data collection on personality traits, the participants provided responses on brand personality scale (BPS: Aaker, 1997) for each of the brands. Print advertisement of the IT brands selected was used as stimuli to investigate the influence of communications in creating brand personality. Two conditions for exposure to advertisement were manipulated.

\section{Manipulations}

Advertisement stimuli manipulation: Two conditions for exposure to advertisement were manipulated. Print advertisement of the two companies was used as stimuli for the study. After exposure to the print advertisement, one group of participants was asked to respond to the brand personality scale for each of the brands. The other group of participants did not view the advertisement but were asked to think about the brands, how they felt being with the company, and so forth, and then provide responses on the BPS.

Personal relevance manipulations: Considering that the sample used was a set of final semester MBA students who had indicated their pre-placement interests, the authors choose to use this information to manipulate personal relevance or involvement conditions. Given that information technology (IT) is a popular industry among MBA students, that has high remuneration structure and high awareness, IT corporate brands were selected for further analysis. Based on the preferences provided for IT industry, the participants were assigned to high involvement condition (ranked IT as most preferred industry) and low involvement conditions (ranked IT as least preferred industry).

\section{Analysis}

Paired sample t-test and multivariate analysis of covariates (MANCOVA) was applied to investigate how individual's personality influenced the perception of brand personality. For MANCOVA, scales computed for the brand personality dimensions were used as dependant variables. The two conditions of advertisement exposure were considered as fixed factors with human personality dimensions and personal relevance used as covariates. Statistical analyses were performed with SPSS version 16.0 for windows.

\section{RESULTS}

Paired Sample t-test: The paired sample t-test indicated that the participants had perceived the brands to be significantly different on the brand personality dimensions. In the group that was not exposed to the stimuli, there were significant differences between the two brands on four personality dimension: Excitement $(\mathrm{MHCL}=3.27<\mathrm{MApple}=4.36, \mathrm{p}<.001)$; Competence $(\mathrm{MHCL}=3.96<$ MApple $=4.24, \mathrm{p}<.001)$; Sophistication $(\mathrm{MHCL}=2.74<$ MApple $=3.78, \mathrm{p}<.001)$; Ruggedness $(\mathrm{MHCL}=2.88<$ MApple $=3.14, \mathrm{p}<.041)$. In the experiment condition exposed to the advertising stimuli, similar results were obtained. The mean values and significant levels for brand personality dimensions were: Sincerity (MHCL = $3.58>$ MApple $=3.19, \mathrm{p}<.001)$, Excitement $(\mathrm{MHCL}=3.04<$ MApple $=4.15, \mathrm{p}<.001)$; Competence $(\mathrm{MHCL}=3.35<\mathrm{MApple}=3.78, \mathrm{p}<.001)$; Sophistication $(\mathrm{MHCL}=2.34<$ MApple $=3.52, \mathrm{p}<.001)$. Generally, the brand personality perception for Apple was more favorable than HCL in both experiment conditions. 
Similarly, paired sample t-test between the two experiment conditions of advertisement seen and not seen present interesting results. For HCL, significant differences were observed for brand personality dimensions-Sincerity $($ Madseen $=3.588>$ Madnot $=3.235, \mathrm{p}=.002)$, Competence $($ Madseen $=3.359<$ Madnot $=3.949, \mathrm{p}<.000)$, and Sophistication $($ Madseen $=$ $2.349>$ Madnot $=2.682, \mathrm{p}=.012$ ). For Apple significant difference was observed for four brand personality dimensions namely Sincerity $($ Madseen $=3.197<\operatorname{Madnot}=3.375, \mathrm{p}=.088)$, Excitement $($ Madseen $=4.153<$ Madnot $=4.366, p=.036)$, Competence $($ Madseen $=3.784<$ Madnot $=4.239, \mathrm{p}<.000)$ and Sophistication $($ Madseen $=3.521<\operatorname{Madnot}=3.7663, \mathrm{p}=.049)$. The results suggest that stimuli used (print advertisement) significantly influenced the brand personality perceptions. Tables 1 and 2 present the descriptive statistics and the correlations between variables for HCL and Apple brands.

MANCOVA: The data were further analyzed for each brand using a MANCOVA to assess how perception of brand personality was affected by the individual's personality dimension. Pillai's Trace is used to ensure the model is not homogeneous for the inequality of means across groups and the covariate (Tabachnick and Fidell, 1996). In case of HCL, the covariate openness to experience was moderately significant with a Pillia's Trace of .074, F $=1.937, \mathrm{p}=.093$ with observed power of .638. The independent variable advertising exposure has a Pillai's Trace of $.329, \mathrm{~F}=11.852, \mathrm{p}<.000$ with observed power of 1.000 . Tests of between subjects effects show that advertising exposure has significant influence on three dimensions of brand personality (sincerity: $\mathrm{F}=6.539, \mathrm{p}=.012$, observed power $=.718$; competence: $\mathrm{F}=29.848, \mathrm{p}<.000$, observed power $=1.000$; sophistication: $\mathrm{F}=10.094, \mathrm{p}=.002$, observed power $=.883$ ). Among the personality dimensions used as covariates, openness to experience shows significant impact on brand personality dimensions-sophistication $(\mathrm{F}=9.310, \mathrm{p}=.003$, observed power $=.857)$, excitement $(\mathrm{F}=3.640, \mathrm{p}=.059$, observed power $=.473)$ and competence $(\mathrm{F}=3.221, \mathrm{p}$ $=.075$, observed power $=.059)$. Conscientiousness shows significant influence on brand personality dimensions of ruggedness $(\mathrm{F}=5.768, \mathrm{p}=.018$, observed power $=.664)$ and competence $(\mathrm{F}=3.031, \mathrm{p}=.084$, observed power $=.408)$.

In case of Apple, the independent variable advertising exposure has a Pillia's Trace of .139, $\mathrm{F}=3.892, \mathrm{p}<.005$ with observed power of .935 . Tests of between subjects effects show that advertising exposure has significant influence on three dimensions of brand personality including excitement $(\mathrm{F}=4.552, \mathrm{p}=.035$, observed power $=.562)$, competence $(\mathrm{F}=18.627, \mathrm{p}$ $<.000$, observed power $=.990)$ and sophistication $(\mathrm{F}=5.032, \mathrm{p}=.027$, observed power $=.605)$. The covariate of agreeableness showed significant effect on excitement $(F=4.868, p=.029$, observed power $=.591)$. Neuroticism has a significant impact on sophistication $(\mathrm{F}=3.410, \mathrm{p}=$ .067 , observed power $=.449$ ). The interaction between advertising exposure and personal relevance was non-significant in influencing the brand personal perceptions for both brands.

The MANCOVA results confirm that individual's personality does influence the perception of certain dimensions of brand personality. It is interesting to note, however, that this effect of the individual's personality on brand personality is different for HCL and Apple. Further, personal relevance was non-significant in influencing the perception of brand personality. 
Table 1. Correlations between the variables for $\mathrm{HCL}$

\begin{tabular}{|l|c|c|c|c|c|c|c|c|c|c|c|c|}
\hline \multicolumn{1}{|c|}{$\mathrm{N}(135)$} & $\mathrm{M}$ & $\mathrm{SD}$ & 1 & 2 & 3 & 4 & 5 & 6 & 7 & 8 & 9 & 10 \\
\hline 1. Sincerity & 3.41 & 0.67 & $(0.78)$ & & & & & & & & & \\
\hline 2. Excitement & 3.16 & 0.78 & $0.17^{* * *}$ & $(0.74)$ & & & & & & & & \\
\hline 3. Competence & 3.67 & 0.67 & $0.19^{* *}$ & $0.54^{*}$ & $(0.74)$ & & & & & & & \\
\hline 4. Sophistication & 2.55 & 0.73 & 0.07 & $0.61^{*}$ & $0.53^{*}$ & $(0.72)$ & & & & & & \\
\hline 5. Ruggedness & 2.87 & 0.74 & $0.14^{* * *}$ & $0.41^{*}$ & $0.36^{*}$ & $0.42^{*}$ & $(0.87)$ & & & & & \\
\hline 6. Extroversion & 3.61 & 0.64 & $0.16^{* * *}$ & -0.10 & $-0.16^{* * *}$ & -0.06 & 0.05 & $(0.70)$ & & & & \\
\hline 7. Agreeableness & 4.16 & 0.48 & 0.09 & -0.09 & -0.10 & -0.06 & -0.10 & 0.09 & $(0.68)$ & & & \\
\hline 8. Concientiousness & 3.81 & 0.59 & 0.11 & 0.08 & 0.06 & -0.02 & 0.12 & -0.01 & $0.35^{*}$ & $(0.89)$ & & \\
\hline 9. Neurotism & 2.50 & 0.73 & -0.40 & 0.02 & 0.11 & 0.07 & 0.06 & -0.12 & $-0.48^{*}$ & -0.458 & $(0.87)$ & \\
\hline 10. Openness & 3.82 & 0.45 & -0.03 & $-0.18^{* *}$ & $-0.19 * *$ & $-0.26^{*}$ & -0.09 & $0.22^{* *}$ & $0.22^{* *}$ & $0.16^{* * *}$ & $-0.21^{* *}$ & $(0.72)$ \\
\hline
\end{tabular}

a Alphas are in parentheses along the diagonal

$*$ - $\mathrm{p}<0.01, * *-\mathrm{p}<0.05, * * *-\mathrm{p}<0.10$

Table 2. Correlations between the variables for Apple

\begin{tabular}{|l|c|c|c|c|c|c|c|c|c|c|c|c|}
\hline \multicolumn{1}{|c|}{$\mathrm{N}(135)$} & $\mathrm{M}$ & $\mathrm{SD}$ & 1 & 2 & 3 & 4 & 5 & 6 & 7 & 8 & 9 & 10 \\
\hline 1. Sincerity & 3.29 & 0.56 & $(0.81)$ & & & & & & & & & \\
\hline 2. Excitement & 4.26 & 0.56 & 0.12 & $(0.72)$ & & & & & & & & \\
\hline 3. Competence & 4.02 & 0.62 & $0.33^{*}$ & $0.47^{*}$ & $(0.70)$ & & & & & & & \\
\hline 4. Sophistication & 3.65 & 0.67 & $0.23^{*}$ & $0.36^{*}$ & $0.34^{*}$ & $(0.79)$ & & & & & & \\
\hline 5. Ruggedness & 3.03 & 0.82 & $0.15^{* * *}$ & $0.27^{*}$ & $0.48^{*}$ & $0.38^{*}$ & $(0.78)$ & & & & & \\
\hline 6. Extroversion & 3.61 & 0.64 & -0.07 & 0.06 & -0.12 & 0.024 & 0.01 & $(0.70)$ & & & & \\
\hline 7. Agreeableness & 4.17 & 0.48 & -0.08 & $-0.16^{* * *}$ & -0.08 & -0.06 & $-0.16^{* * *}$ & 0.09 & $(0.68)$ & & & \\
\hline 8. Concientiousness & 3.81 & 0.59 & -0.05 & 0.09 & -0.01 & -0.05 & -0.07 & -0.01 & $0.35^{*}$ & $(0.89)$ & & \\
\hline 9. Neurotism & 2.50 & 0.73 & -0.05 & -0.03 & 0.03 & -0.11 & 0.05 & -0.12 & $-0.47^{*}$ & $-0.44 *$ & $(0.87)$ & \\
\hline 10. Openness & 3.82 & 0.45 & 0.09 & -0.10 & -0.12 & -0.05 & -0.06 & $0.22 * *$ & $0.22^{* *}$ & $0.16^{* * *}$ & $-0.21^{* *}$ & $(0.72)$ \\
\hline
\end{tabular}

a Alphas are in parentheses along the diagonal

$*$ - $\mathrm{p}<0.01, * *-\mathrm{p}<0.05, * * *-\mathrm{p}<0.10$ 


\section{DISCUSSION, IMPLICATIONS AND LIMITATIONS}

\section{Discussion of Results}

Consistent with previous studies in the context of brand personality (Ruiz and Sicilia, 2004) and communication processing (Matzler et al., 2006) it has been shown that the individual's personality moderates the relationship between advertising communication and perception of brand personality being communicated.

The paired sample t-test indicates that participants perceived the two brands' personality as different and distinct. Significant difference is presented in the perception of brand's personality between groups exposed to advertisement and not exposed to advertising. For experiment condition exposed to advertising, Apple was rated lower on brand personality dimension of sincerity than for HCL. On other personality dimensions, Apple was rated significantly more favorable than HCL. The results suggest that the participants perceived distinct personalities for the two brands.

The results from the paired sample t-test across the two experiment conditions of advertising exposure suggest that advertising or marketing communication influenced the perception of brand personality dimension for both brands. It is interesting, however, to note that the print advertisements shown significantly lowered the perception of the two brands on most personality dimensions. The exception was observed in case of HCL, where exposure to the print advertisement significantly improved the perception of personality dimension 'sincerity'. Thus, managers can use specific marketing communication programs to improve or position the target markets' perception of its brand personality.

The results from MANCOVA with individual personality dimensions as covariates confirm the main-effects and covariate influence in brand personality perceptions. Advertising exposure had significant main effect on brand personality dimensions. Tests of between subjects show that the advertising used influenced certain brand personality dimensions. In case of HCL, it significantly influenced the perception of sincerity, competence and sophistication. However, for Apple, the print advertisement shown has significant effect on excitement, competence and sophistication. The above findings confirm the results of earlier studies indicating the key role of advertising in creating and influencing brand personality perceptions (Batra et al., 1993; Meenaghan, 1995; Ang and Lim, 2006).

An important contribution of this study is that we found significant moderating effect of individual personality in brand personality perception. In case of HCL, openness to experience influences sophistication, excitement and competence, and conscientiousness impacts competence and ruggedness. For Apple, personality dimension agreeableness showed significant impact on excitement, while neuroticism influenced sophistication. For HCL, personality dimensions of openness to experience and conscientiousness reduces the perception of competence and sophistication for the print advertisement shown. However, it is interesting to note that the significant increase in sincerity perception is not moderated by the individual personality dimensions. In case of Apple, agreeableness and neuroticism decrease the favorableness of the brand personality dimensions of excitement and sophistication respectively. This indicates that for specific brands, the communication program may be influenced by one or more dimensions of individual personality of the target audience.

The lack of significant interaction effects for personal relevance indicates that perhaps, in this study, personal relevance has little role to play in influencing or moderating the perception of brand personalities. 


\section{Implications}

The results of this study could have important implications for marketers in terms of positioning and communicating a brand personality. The study indicates that while exposure to advertising can influence perception of brand personality dimension, it is important to check whether the required perception of brand personality is in fact deciphered by consumers processing the information from the advertisement. It is understood that brands are positioned vis-à-vis the target market; nevertheless, it may be pertinent to point out that taking into consideration the dominant personality traits of the target audience and how they relate to the brand can be important for the success of brand positioning and communication. For marketers, it may be well worth the exercise to identify the personality characteristics of the target audience and then put together a communication that can influence the perception of required traits of the brand that the marketer hopes to highlight.

\section{Limitations}

While the study has its limitations in terms of adequacy of significance levels, the study nevertheless indicates the moderating role of individual's personality in brand personality perceptions. The limitations may be due to the choice of brands in this study, which were chosen in order to make them relevant for the sample, as well as the fact that these are corporate brands as opposed a product or service brands. The study does not reiterate the importance of personal relevance as indicated in other studies. For a study that focused on marketing communication among a group of students geared for employment, perhaps, a high level of awareness of these brands might have impeded the role of personal relevance in information processing. Further investigation of the influence of individual personality dimensions on brand personality dimensions using other brands with clear brand personality communications may yield better results. 


\section{REFERENCES}

Aaker, D. A. (1996). Measuring brand equity across products and markets. California Management Review, 38(3), 102-120

Aaker, J. L. (1997). Dimensions of brand personality. Journal of Marketing Research, 34 (2), 347-356.

Aaker, J. L. (1999). The malleable self: the role of self expression in persuasion. Journal of Marketing Research, 36(1), 45-57.

Aaker, J. L. Benet-Martinez and Garolera. (2001). Consumption symbols as carriers of culture: A study of Japanese and Spanish brand personality constructs. Journal of Personality and Social Psychology, 81 (3), 492-508.

Ajzen, I. (2005). Attitudes, Personality and Behavior. 2nd ed. Open University Press: Milton Keynes.

Allport, G. W., and Odbert, H. S. (1936). Trait names: A psycholexical study. Psychological Monographs 47: Whole no. 211.

Ang, S. M., and Lim, E. A. C. (2006). The Influence of Metaphors and Product Type on Brand Personality Perceptions and Attitudes. Journal of Advertising, 35(2), 39-54.

Barrick, M. R., and Mount, M. K. (1991). The Big Five personality dimensions and job performance: A meta-analysis. Personnel Psychology, 44, 1-26

Batra, R., Lehmann, D., and Singh, D. (1993). The Brand Personality Component of Brand goodwill: Some Antecedents and Consequences. In Aaker, D., and Biel, A. L. (Eds.), Brand equity \& advertising: advertising's role in building strong brands (pp. 83-95). Hillsdale: Lawrence Erlbaum.

Berger, I. E., and Mitchell, A. (1989). The effect of advertising on attitude accessibility, attitude confidence, and the attitude-behavior relationship. Journal of Consumer Research, 16, 269-279

Blythe, J. (2007). Advertising creative and brand personality: A grounded theory perspective. Journal of Brand Management, 14 (4), 284-295

Bozionelos, G., and Bennett, P. (1999). The theory of planned behaviour as predictor of exercise: The moderating influence of beliefs and personality variables. Journal of Health Psychology, 4, 517-529.

Caprara, G. V., Barbaranelli, C., and Guido, G. (2001). Brand personality: How to make the metaphor fit? Journal of Economic Psychology, 22, 377-395.

Cattell, R. B. (1943). The Description of Personality: Basic Traits Resolved Into Clusters. Journal of Abnormal Social Psychology, 38, 476-506.

Celsi, R., and Olson, J. 1988. The role of involvement in attention and comprehension processes. Journal of Consumer Research 15, 210-224.

Chaiken, S. (1980). Heuristic versus systematic information processing in the use of source versus message cues in persuasion. Journal of Personality and Social Psychology, 39, 752766. 
Cooper, D. (2003). Psychology, risk and safety. Professional Safety, 48 (11), 39-46.

Costa, P.T., Jr., McCrae, R. R., and Dye, D.A. (1991). Facet scales for Agreeableness and Conscientiousness: A revision of the NEO Personality Inventory. Personality and Individual Differences, 12, 887-898.

Dollinger, S. M. C., (1995). Identity styles and the five-factor model of personality. Journal of Research in Personality, 29, 475-479.

Duhachek, A., and Iobucchi, D. Consumer personality and coping: Testing rival theories of process. Journal of Consumer Psychology, 15 (1), 52-61.

Eagly, A. H., and Chaiken, S. (1984). Cognitive theories of persuasion. Advances in Experimental Social Pyschology, 17, 267-359.

Fennis, B.M. and Ad Th. H. Pruyn. (2007). You are what you wear: Brand personality influences on consumer impression formation. Journal of Business Research, 60, 634-663.

Fennis, B.M., Ad Th. H. Pruyn and Maasland M. (2005). Revisiting the malleable self: Brand effects on consumer self-perceptions of personality traits. Advances in Consumer Research, 32, 371-377.

Fournier, S. (1998). Consumers and their brands: Developing relationship theory in consumer research. Journal of Consumer Research, 24 (1), 343-73.

Fiske, D. W. (1949). Consistency of the factorial structures of personality ratings from different sources. Journal of Abnormal Social Psychology, 44, 329-44

Freling, T. H. and Forbes, L. P. (2005). An empirical analysis of the brand personality effect. Journal of Product \& Brand Management, 14 (7), 404-413.

George, J. M. and Zhou, J. (2001). When openness to experience and conscientiousness are related to creative behavior: an interactional approach. Journal of Applied Psychology 86, 513 524

Goldberg, L. R. (1981). Language and individual differences: the search for universals in personality lexicons. In Wheeler (Ed.), Review of Personality and Social Psychology, (14165). Beverly Hills, CA: Sage

Grubb, E. L. and Hupp, G. (1968). Perception of self, generalized stereotypes, and brand selection. Journal of Marketing Research, 1(5), 58-63.

Hamm, B. C., and Cundiff, W. E. 1969. Self actualization and product perception. Journal of Market Research, 6, 470-47.

Helgeson, J. G., and Supphellen, M. (2004). A conceptual and measurement comparison of self-congruity and brand personality-The impact of socially desirable responding. International Journal of Market Research, 46 (2), 205-233.

Hills, P., and Argyle, M. (2001). Emotional stability as a major dimension of happiness. Personality and Individual Differences, 31, 1357-1364.

John, O. P., and Srivastava, S. (1999). The Big Five trait taxonomy: History, measurement, and theoretical perspectives. In Pervin, L. A., and John, O. P. (Eds.), Handbook of personality: Theory and research 2nd ed. (102-138), New York: Guilford Press. 
Kaltcheva, V. D. and Parasuraman, A. (2008). Personality-Relatedness and Reciprocity framework for analyzing retailer-consumer interactions. Journal of Business Research 62 (6), 601-608.

Keller, K. L. 1998. Strategic Brand Management: Building, Measuring and Managing Brand Equity. New Jersey: Prentice Hall

Kim, Hae Ryong, Lee, M., and Francis U. M. (2005). Brand personality, self-congruity and the consumer-brand relationship. Asia Pacific Advances in Consumer Research, 6, 111-117

Kressman F, Sirgy M. J., Herrman, A., Huber, F., Huber, S., and Lee D-J. (2006). Direct and indirect effects of self-image congruence on brand loyalty. Journal of Business Research, 59 (6), 955-964.

Mangleburg, T. F., Sirgy M. J., Grewal, D., Axsom, D., Hatzios, M., Claiborne, C. B., and Bogle, T. (1998). The moderating effect of prior experience in consumers' use of user-image based versus utilitarian cues in brand attitude. Journal of Business and Psychology, 13 (1), 101113.

Martineau, P. (1958). The personality of the retail store. Journal of Retailing, 52, 37-46.

Matzler K., Sonja, B., and Grabner-Krauter, S. (2006). Individual determinants of brand affect: the role of the personality traits of extroversion and openness to experience. Journal of Product and Brand Management 15 (7), 427-434.

McCracken, G. (1989). "Who is the Celebrity Endorser? Cultural Foundations of the Endorsement Process. Journal of Consumer Research, 16, 310-320.

McCrae, R. R. (1994). Openness to Experience: Expanding the Boundaries of Factor V. European Journal of Personality, 8, 251-72.

McCrae, R. R. and Costa, P. T., Jr. 1990. Personality in adulthood. New York: The Guildford Press.

MacInnis, D. J., and Jaworski B. J. (1989). Information processing from advertisements: Toward an intergrative framework. The Journal of Marketing, 53, 1-23.

Meenaghan, T. (1995). The role of advertising in brand image development. Journal of Product \& Brand Management, 4 (4), 23-34.

Moon, Y. (2002). Personalization and personality: Some effects of customizing message style based on consumer personality. Journal of Consumer Psychology, 12 (4), 313-326

Mooradian, T. A. and Swan K. S. (2006). Personality-and-culture: The case of national extraversion and word-of-mouth. Journal of Business Research, 59 (6), 778-785.

Mowen, J. C., Park, S., and Zablah, A. (2007). Toward a theory of motivation and personality with application to word-of-mouth communications. Journal of Business Research, 60 (6), 590-596.

Petty, R. E., Cacioppo, J. T., and Schumann, D. (1983). Central and peripheral routes to advertising effectiveness: The moderating role of involvement. Journal of Consumer Research, 1, 135-146. 
Petty, R. E., and Cacioppo, J. T. (1986). Communication and Persuasion. New York: SpringerVerlag.

Petty, R. E., Cacioppo, J. T., and Goldman, R. (1981). Personal involvement as a determinant of argument-based persuasion. Journal of Personality and Social Psychology, 41(5), 847-855.

Phau, I. and Lau, K. 2001. Brand personality and consumer self-expression: Single or dual carriageway? Journal of Brand Management 8 (6), 428-444.

Plummer, J. T. 2000. How Personality Makes a Difference. Journal of Advertising 40 (4), 7984.

Richins, M. L., and Bloch, P. H. (1986). After the news wears off: The temporal context of product involvement. Journal of Consumer Research, 13, 280-285

Ruiz, S., and Sicilia, M. (2004). The impact of cognitive and/or affective processing styles on consumer response to advertising appeals. Journal of Business Research, 57 (6), 657- 664.

Sirgy, J. M. (1982). Self concept in consumer behaviour: a critical review. Journal of Consumer Research, 9, 287-300.

Smith, G. M. (1967). Usefulness of peer ratings of personality in educational research. Educational and Psychological Measurement, 27, 967-84

Sung, Y. and Tinkham, S. F. (2005). Brand personality structures in the United States and Korea: Common and culture-specific factors. Journal of Consumer Psychology, 15 (4), 334-350.

Tabachnick, B. G., and Fidell, L. S. (1996). Using multivariate statistics (3rd Ed.). New York: Harper Collins.

Wee, T. T. T. (2004). Extending human personality to brands: The stability factor. Journal of Brand Management, 11(4), 317-330. 